\title{
Linguistic Cases among the Takalar Resort Police, South Sulawesi: Forensic Linguistic Research
}

\author{
Jusmianti Garing ${ }^{1}$, Ratnawati ${ }^{2}$, Asri M. Nurhidayah ${ }^{3}$, \\ garingjusmianty@yahoo.co.id ${ }^{1}$, ratnawati2409@yahoo.com ${ }^{2}$, \\ asrim.nurhidayah@yahoo.co.id ${ }^{3}$ \\ Balai Bahasa Sulawesi Selatan, Tala Salapang, Makassar ${ }^{1}$, Balai Bahasa Sulawesi Selatan, Tala \\ Salapang, Makassar ${ }^{2}$, Balai Bahasa Sulawesi Selatan, Tala Salapang, Makassar ${ }^{3}$
}

\begin{abstract}
The research explores phenomena in the form of spoken or written speech, both within and without social media. The study applies a descriptive approach, which is describing and analyzing pragmatic elements. The data gathering techniques include: selecting and explaining the Police Investigation Report (BAP) related to this research. Data analysis conducted in-depth reading, highlighting keywords and ideas relevant to the discussion, and interpreting said words based on the pragmatic theory. The results indicate the speech and word or sentence in the Police Investigation Report (BAP) at the Takalar Resort Police contain criminal offenses. The criminal offenses seem on the presupposition, conversation implicature, and speech acts view. These views found that languages on the BAP highlighted by using provocateurs language, decency violations, embarrassing, threatening, slandering, humiliating, and defaming either in social media or no social media, either in printed media or unprinted media.
\end{abstract}

Keywords: forensic linguistics, linguistic cases, linguists, defamation, criminal offenses.

\section{Introduction}

A language is a communication tool used by speakers to express the heart and mind; reflecting, the ability or competence of a speaker. Even though only one language has been used, the method of use is different for each speaker. Besides, the ways and objectives achieved by using the language have adapted to each position and capacity. By relying on the rationale for language as a means of communication, naturally, the language used must also be communicative. Excellent communication will bring good communication.

Conversely, the failure of communication will lead to a misunderstanding resulting in a chaotic $^{1}$ connection. Excellent communication occurs in two ways, i.e., between the speaker and the addressee. When the speakers and the addressee are not connected in conversation, they sometimes attack each other using language that can trigger arguments or quarrels. Not a few communications that result in a dispute or quarrel up to the realm of law. This communication usually happens either on social media or on social media. Either upon printed media or nonprinted media. The role of social media considerably impacts communication, which adversely affects language users themselves. These adverse effects seem in the rise of

${ }^{1}$ Chaotic is a meaningful mess caused by a misunderstanding in interpreting something. 
criminal acts that the police have recently handled, such as humiliation, defamation, slander, provocation, and expressions of hatred, especially those dealing with ethnic, religious, racial, and intergroup relations (SARA). The criminal Act arises from communication in the form of speech, which is not directed and controlled, thus in the legal process, the handling of such cases considerably needed a linguist to verify. The linguist's statement is expected to assist the judge in making a decision. In this case, the knowledge of a linguist must qualify. Thus, the information given is accurate, and a linguist's presence in a legal case is constitutional evidence.

The criminal case mentioned is the result of a linguist's information based on the analysis from the language perspective. These criminal cases have a close relationship between language and law. This relationship is called forensic linguistics. Forensic linguistics is a branch of linguistics that discusses the relationship between language, law, and crime. Forensic linguistics had studied the language used in cross-examination, evidence of presentation, the direction of judges, concluding judges, police warnings, police speaking, technical interviews, interrogation processes in court, and police interviews [1]. It means that forensic linguistics is a branch of linguistics, which examines the language as a proving tool in the judiciary and the legal field, and it very much needs in analyzing the evidence of the justice component in the form of language for doing the investigation, either in civil or criminal cases. [2] said that forensic linguistics was the scientific study of language that aimed to solve forensic queries. In other words, forensic linguistics was an applied linguistic field that tried to analyze linguistic evidence scientifically of a crime for law enforcement purposes. $\mathrm{He}$ had further stated that forensic linguistics was the application of the principles and linguistic study method in legal cases and law enforcement. In justice, a law case, forensic linguistics performed by a linguist. Indonesian law had stated that expert witness statements were valid evidence [3]. Furthermore, Saletovic and Kisicek in [4] declared that this science was a branch of applied linguistics that examined the interaction among language, crime, and law. The same thing was also expressed by Olsson in [4], who said that knowledge and linguistic techniques applied in forensic linguistics to examine linguistic phenomena related to legal cases or personal disputes between several parties, which in the next stage had an impact on taking legal action.

Issues that are forensic linguistics scope is identifying speakers based on dialect, style of speech, or accent. Thus, it sometimes needs to analyze the suspect's handwriting to obtain its profile and analyze the speech content and meaning in the linguistic context used as judicial evidence. Furthermore, the things that need to keep in the mind of the linguist witness realized the self-limitations, explained the analysis limitation to the investigator or client, accepted or rejected the case, do not promise results, and assessed the data before approving and signing the Police Investigation Report $\left(\mathrm{BAP}^{2}\right)$. Linguistic witnesses rights and obligations, namely having secure data storage, pre-assessing data received from lawyers or police, asking for the case chronology to be analyzed, avoiding contamination of findings with an unconscious bias, setting a reasonable time frame, and asking for clarity of fees, including fees for an initial assessment. Moreover, Shinder in [5] had explained some factors and criteria that would be owned by an expert witness. These factors and criteria were having a higher education degree or advanced training in a specialized field, having specific specializations, recognition as a teacher, lecturer, or following training in the appropriate field. The same was

\footnotetext{
${ }^{2}$ Police Investigation Report (BAP) has written evidence of an investigation, consisting of several sheets of questions and answers among the investigator and the investigated party, and the elements that are subject criminal.
} 
also expressed by [6] that an expert witness allowed in giving opinion testimony in a trial based on his knowledge, training, or experience. If the opinion is reliable and relevant to the case, it helps the factfinder make a decision. Based on the factors and criteria that must be possessed by an expert witness, it is clear that an expert must be qualified and has knowledge relevant to his specialized profession. The relevant bibliography will make an expert professional, and his capabilities as an expert will not deny anymore. Besides, experiences as expert witnesses are also factors that should be owned by an expert. Thus, his testimony becomes accountable and credible when determining if someone is suspect ${ }^{3}$ or not. $^{2}$

Linguistic levels are related to forensic linguistics including discourse analysis, semantics, and pragmatics. [7] assumed that pragmatics was a study of utterance or speech. For this reason, speakers try to make the communication continuously relevant to the context, clear, easy to understand, compact, concise, and always at the point of the problem. Speech contexts are represented as aspects that are relevant to the physical and social environment of communication. The purpose of the speech is the intention of the speaker to deliver the speech. Pragmatics, in particular, examines the language structure externally [8]. It means how linguistic units are used in the statement; and how they interpret the speech to the addressee (reader). The same opinion declared by [9], pragmatics was the study of language use. Furthermore, [10] was stated that pragmatics examined meaning concerning speech situations. Based on this view, pragmatics discusses the role of setting or the use of language itself, spoken by speakers through speech. Interpretation of a particular context and how it influences what is said is essential in speaking. Views also connected to the argument that the study of language in the form of speech was part of a pragmatic study, which examined the use of language in communication, particularly the relationship among sentence, the context, and its use situation [11]. It needs to consider how the speaker communicates what they want to convey based on the case. Hence, pragmatics examines the relationship between language elements associated with the speakers. Pragmatics includes; (1) presuppositions, (2) conversational implicature, and (3) speech acts. According to [12], the presuppositions were the basis inference of the context and language situation that made language form (sentence or expression) had meaning to language receiver, and vice versa, helped the speaker determined the language forms, which used to represent the meaning. At the same time, conversational implicature is indirect meanings generated by the statement. Conversational implicatures are intended as an utterance that implies something different from what is said. Therefore, conversational implicature means to suggest something indirectly. This perspective is accordingly to [13]; conversational implicature was another meaning derived from an utterance. In other words, implications are hidden intentions, desires, or expressions of the heart. Hereafter, pragmatics is a speech act. A speech act examines the language meaning based on the speech relationship with the speaker's action to the addressee. In other statements, the speech will be meaningful if real actions realize it. Austin, in [11], also sees [14], mentioned that speech acts consisted of three aspects of meaning, i.e., the locution speech act, the illocution speech act, and the perlocution speech acts. The locution speech act is the meaning of a word that reveals a thing clearly without other interests. This meaning usually is included in such cases of news sentences, statement sentences, and declarative sentences. In further [14], stated that illocutionary acts were telling, commanding, reminding, and implementing the form. Moreover, Levinson in [15] had declared that the perlocution speech

\footnotetext{
${ }^{3}$ The suspect is someone who is committing a legal violation in linguistics forensic either in spoken or written speech.
} 
act was more concerned by results, due to the action said successfully when the addressee did something desired by the speaker. The three aspects of speech acts are very relevant in identifying and revealing the language cases at Takalar Resort Police as outlined on the BAP.

Takalar Regency ${ }^{4}$, as the research location, is the closest regencies to Makassar City, which makes it easy for social contact between the two communities. The distance from Makassar City to Takalar Regency is only about 46 kilometers. The range allows the two areas to have a lifestyle that is digital and modern. This situation certainly has good and bad consequences for both communities. Digital influence, for instance, has many incredible benefits and have unfavorable effects, such as the rise of criminal cases that happened in Takalar Regency nowadays. One of the crimes referred to is the rampant cases of defamation, occurs in this regency. This issue affected by modernization and digitalization, which is very sophisticated and fast and supported by using uncontrolled language, thus not a few people stumbled legal cases. The language case in this regency is rampant happens. Reporting Person and Reported Person do not look at age, education, and strata of life anymore. These phenomena are the reasons for doing this research.

\section{Research method}

The method used in this research is the descriptive method, which is describing and studying linguistic elements, incredibly pragmatic elements, which a re issued in the Police Investigation Report (BAP) of the Takalar Resort Police. The technique used to obtain data or information needed in this research is selecting and analyzing the Police Investigation Report (BAP) related to this research based on the pragmatics and speech act perspective. Data analysis consists of in-depth reading, highlighting keywords and ideas relevant to the discussion at hand, and interpreting said words based on the pragmatic theory.

\section{Result and discussion}

The result of pragmatics and speech act perspective found some linguistic cases among the Takalar Resort Police. Most linguistic cases occur on social media such as Facebook, Whatsaap, Messenger, and Chat and in election cases. These linguistics cases contain criminal offenses, including provocateurs, violations of decency, embarrassing, threatening, humiliating, and defaming meaning. These linguistics cases seem in the following discussion.

\subsection{Criminal Election}

Election criminal case has tangled up the head of the village in Polombangkeng Utara Subdistrict with indictment due to acting purposely to benefit or harm one of the legislative election participants during the campaign period.

A person who is a headman initialed, MS Dg. $\mathrm{K}$ is reporting to the General Election Watch Board of the Takalar Regency due to 'order' his communities to elect Mr. HK in the Legislative Election of Indonesian Representatives Council of 2019 to 2024. MS Dg. K, as a

\footnotetext{
${ }^{4}$ Takalar Regency is one of the districts located in South Sulawesi Province, Indonesia.
} 
Reported Person, is accompanying HK as legislative candidates; and speaks to the community who gather at the meeting hall as follows.

Thus, everyone already knows the purpose he is coming here. It is not aimless face to face with all of you. He wants your nails at eee the year of 2019. It's not good if it's not supported. Thus, I ask you all don't just nod in front of me because I feel embarrassed also beside him of Mr. HK...

The pragmatic analysis of the speech above is as follows.

In the presupposition perspective, MS Dg. K, as the Reported Person, is using the Makassarese language mixed with a little Indonesian language, the term 'nail tip' due to the MS Dg. K has previously assumed that their villagers understood the implementation of elections; the voters will use 'nail tips' to vote their photos and names of their choice. In the conversational implicature perspective, MS Dg. K has said in the Makassarese language mixed with a little Indonesian language. He has begged once that the residents of his village chose Mr. HK.

In the speech acts perspective, in particular the locution aspect, MS Dg. K informs the intent and purpose of holding a meeting at the village hall, especially approaching the holding the Legislative Election of Indonesian Representatives Council from 2019 to 2024. Furthermore, from the illocutionary aspect, the statement Erokinjo He wants the tips of your nail has the implicit meaning. The sentence means that the local villagers will vote for him in the Legislative Election of Indonesian Representatives Council from 2019 to 2024. From the perlocution aspect, the meaning or attitude of the villagers to the statement heard, whether they will obey or reject the request of MS Dg. K to vote a photo and name of the HK candidate in the legislative election.

\subsection{Violation of Decency}

A case of decency violation that has ensnared a young man, initials AG, as the owner and user of the Facebook of SC, has reported by someone. The Reporting Person ${ }^{5}$ is a woman, initials AS. Originally, AG and AS meet through cyberspace Facebook. The acquaintanceship makes them more familiar and continues by giving each other the mobile/WhatsApp numbers. When AG and AS chat privately via video call on WhatsApp, AG tells AS to opening her clothes. Thus, her breasts are apparent. AG also screenshots several of his colleagues on SC Facebook. Several days later, one of AS teacher comes to the AS home and reports the screenshot photo of AS to her parents while asking, is it true that AS is in that photo?

The investigator is questioning AS about his belief that the posting of SC on Facebook has content that violates decency through social media, and it can see commonly. For the investigator's question, AS is answering: I can explain that the posting cannot be seen and read generally due to the AG posts it through my Messenger chat.

Pragmatic analysis of the speech based on the presupposition perspective is AS believes that the report is less legally strong due to the posting is done through private chat. In the conversation implicature viewpoint, AS as a Reporting Person is withdrawing his statement, which is judicially robust due to the posting being done via private chat. In the speech acts aspect, particularly of the locution perspective, AS reports a posting that violates the decency on social media, "Facebook" that happens to him. For the illocutionary view, the assignment cannot be seen and read commonly because AG posts it in my private chat. This sentence has implied meaning and indicates that AS surrenders to a legal decision that is

\footnotetext{
${ }^{5}$ Reporting Person is individuals or groups or agencies that convey complaints to judicial institutions.
} 
advantageous to AG as a Reported Person ${ }^{6}$. While from the perlocution perspective, it is one meaning or attitude to AS for the investigator's question concerning the violation of decency that AS believes whether it is successful or not.

\subsection{Threatening}

The threatening case suspected is carried out by C to B. Originally, Reporting Person of B sends a message to $\mathrm{C}$ as the head of a department regarding their plans to conduct a demonstration at the official led by $\mathrm{C}$ as a Reported Person. Then, $\mathrm{C}$ threatens through WhatsApp, mostly inline private, by posting the words.

Okay, please do a demonstration, but don't be anarchist because I will respond to you too and yes, that's true, I'll give my life if you want it, boss.

The pragmatic analysis of the statement viewed from the presupposition aspect is B as a Reporting Person convinced that his actions told its plans to hold a protest at the office led by the Reported Person has fulfilled the procedures. However, $\mathrm{C}$ as a Reported Person has considered that the demonstration is an effort to force the will; therefore, it requires handling, by giving the impression that I am not frightened of you.

$\mathrm{C}$ as a Reported Person has challenged in the conversational implicature terms while inviting $\mathrm{B}$ as a Reporting Person, who sends him a message regarding their plan to hold a protest at the office led by the Reported Person. In addition to challenging and inviting demonstrations in his office, the Reported Person also threatens the Reporting Person.

In the speech act perspective, particularly, from the locution aspect, B as a Reporting Person informs the intent and purpose to his group to conduct a demonstration at the office led by the Reported Person; however, received a response is not friendly. Then, the illocutionary aspect seems in the next statements, okay, please do a demonstration but don't be anarchist because I will respond to you too and "Yes, that's true, I'll give my life if you want it, the boss. The sentence has the implicit meaning that $\mathrm{C}$ as a Reported Person is very 'arrogant' to $\mathrm{B}$ and his group. While from the perlocution aspect, which is the meaning or nature of $\mathrm{B}$, is notifying the group's plan to hold a demonstration at the office managed by the Reported Person and the attitude of the Reported Person, is reacted arrogantly.

\subsection{Humiliation or Defamation}

Humiliation or Defamation cases are allegedly performed by AA to NK. Initially, AA as a Reported Person refuels of Pertalite at Batu-Batu ${ }^{7}$ Gas Station. Feeling suspicious that the fuel entered the tank of his vehicle is not following the proper amount.

Pragmatic analysis of the speech seems to work from the presupposition aspect. AA considers that the filling of the Pertalite of Batu-Batu Gas Station does not match the dosage. Then, the conversational implicature perspective also works to the next statement. AA feels as a consumer harmed by fraudulence "deliberate" done by the management of the BatuBatu Gas Station in the form of incompatibility dosage. Furthermore, from the perspective of a speech act, particularly the locution aspect, AA informs that there is cheating the inconsistency between the measure in the form of the fuel oil should be observed. From the illocutionary perspective, the statements "Batu-Batu Gas Station likes playing cheating in reducing the amount of gasoline, not just once ... many times already, there have been many

\footnotetext{
${ }^{6}$ Reported Person is someone who reported for supposedly committing a criminal act.

${ }^{7}$ Batu-Batu is the name of a village located in the District of North Galesong, Takalar Regency.
} 
victims. Where should I report that action?" have the implicit meaning. The statements indicate that AA appears to be 'suspicious' of the the Batu-Batu Gas Station manager's cheating play, which is highly dangerous to himself and consumers. From the perlocution perspective, the meaning or attitude of AA who informs the existence of fraud in the form of discrepancy in the amount of fuel that is inappropriate; this is deliberately done by the manager to gain as much profit as possible. It has been going on for a long time and must be acted upon immediately.

Another case of defamation happens at the Takalar Resort Police goes to FAY and Suleha accounts against SHM. Initially, as a Reported Person, FAY writes humiliation words via Facebook that SHM as a Reporting Person has ever been found naked on the car surrounded by men. A pragmatic analysis viewpoint, particularly at the presuppositions perspective, FAY spreads slander that SHM has been found naked on a car surrounded by men. Then, in the conversational implicature perspective, SHM feels humiliated and losing self-esteem as a woman who has never committed a disgusting act for the behavior carried out by FAY via Facebook. Moreover, in the speech acts perspective, particularly the locution features, FAY informs words or expressions via Facebook that may cause SHM disgraced by his real name. In the illocution perspective, the statement had ever been found naked on the car surrounded by men implies that FAY is trying to defame SHM; and has never committed any acts as alleged by FAY. From the perlocution aspect, it is the meaning or attitude of FAY, which informs that there has been an immoral action is done by SHM on a car, and the Act harms the SHM itself.

The last case concerning humiliation or defamation found in BAP at the Takalar District Police is allegedly committed by AS to E. AS is committing the humiliation or defamation to E by writing on his Facebook.

His mother goes looking for a penis, his family is right, as a buffalo family, all are not well-advised. Instead, they questioned $€ £ ¥$ you all dot fack you $£ ¥ € W$ who feels like it, only interfere.

AS, as the Reported Person, recognizes that she is writing the inappropriate thing on her Facebook due to he is annoying. Therefore, she could not control her words and write them on her Facebook. AS itself is the husband of E as a Reporting Person. E has already been sued for divorce by AS because he often argues regarding economics. In addition to using the Indonesian language, the posting also uses Makassarese and the English language. That Makasarese language uses laso' male genitals/ the penis'; tedong ${ }^{8}$ 'the buffalo'), 'the buffalo'), and the English language is you all dot fack you.

From the pragmatic point of view, especially the presupposition aspect, AS writes on his Facebook that E (his wife) does not take care of their child; his wife goes only looking for a man. Then, in the speech acts perspective, particularly in locution aspects, AS writes on his Facebook that his wife does not take care of their children due to her job is looking only for men. Next, from the illocutionary aspect, the posting implies that his wife is not taking care of their children, and she is only having fun with her family. The posting holds to the public on social media (FB). Things have posted on social media (FB) are unnatural and inappropriate for a husband saying it to his wife and family.

Nevertheless, it is occurring due to he is annoyed with his wife and family. The perlocutionary aspect seems at AS's writing on FB that accuses $\mathrm{E}$ of not taking care of their children, and humiliating E works for looking at a penis only; and his family is a buffalo

${ }^{8}$ Tedong (Buffalo), referred to in this language case, is interpreted as foolish because they like to meddle in their household affairs. 
family. A penis is a male genital. It can interpret as a man. AS thinks his wife is only looking for men. Thus, she doesn't take care of their children. Buffalo people have the meaning of stupid humans or stupid people. AS insults his wife's family as a foolish human who likes to interfere in their household affairs.

\section{Conclusion}

Based on the pragmatics analysis, the linguistic cases that occur at the Takalar

Resort Police contain the meaning of provocateurs, embarrassing, threatening, humiliating, and defaming. It can show from the results of pragmatics and speech acts analysis. The pragmatics appears to the presupposition and conversation implicature perspective. Then, the speech acts point out the locution, illocution, and perlocution perspective. Next, the presupposition perspective seems to work on the BAP at the Takalar Resort Police using code-switching (Makassarese and Indonesian language). They use it when states their intentions and purposes. Most of the societies speak in the Makasarese language. Besides, the speech acts, in particular, the locution aspect, uses provocateurs language when they communicate their intentions and purposes, either in social media or nonsocial media, either in printed media or nonprinted media. The illocution aspect then conveys using the implicit and explicit language on reports that become legal cases in the Takalar Resort Police. The statements contain forensic cases that have uttered by directly or indirectly meaning; and it has given a critical impact on the perpetrator regarding criminal offenses, including violation of decency, embarrassing, threatening, slandering, and humiliating, as well as defaming. The perlocution aspect uses language emphasis in statements that become legal cases in the Takalar Resort Police. It aims to give legal action by his actions.

Acknowledgments. This research is not being possible finished without the help of many people. The support, knowledge, and attention have been an inspiration and kept our work on track from the first doing this research until publishing the research. Especially thanks go to the researchers' team for cooperation during researching without tirelessly. All of you are great researchers. Our thank also goes to the Head of Balai Bahasa, who gave the research permission and the Takalar District government, who permitted us to conduct language studies, especially in the Takalar Resort Police. We are also grateful for the insightful comments recommended by the anonymous peer reviewers before publishing. The kindness and expertise have developed this research in innumerable ways and saved us from errors.

\section{References}

[1] Malcolm Coulthard and Alison Johnson. An Introduction to Forensic Linguistics: Language in Evidence. London and New York: Routledge. 2007. https://pasca.uns.ac.id/s3linguistik/wpcontent/uploads/sites/44/2016/10/Malcolm_Coulthard Alison_Johnson.pdf.

[2] Mahsun, M. Linguistik Forensik: Memahami Forensik Berbasis Teks dengan Analogi DNA. Depok: Rajawali Pers. 2018 https://shopee.co.id/LINGUISTIK-FORENSIK-MEMAHAMIFORENSIK-BERBASIS-TEKS-DENGAN-ANALOGI-DNA-Mahsun i.123558896.2050514675.

[3] Kushartanti, d. Pesona Bahasa: Langkah Awal Memahami Linguistik. Jakarta: PT. Gramedia Pustaka Utama. 2005. https://opac.perpusnas.go.id/DetailOpac.aspx?id=385623.

[4] Santoso. MENGENAL LINGUISTIK FORENSIK: LINGUIS SEBAGAI SAKSI AHLI. Yogyakarta: UNY. 
https://www.academia.edu/12077410/Mengenal_Linguistik_Forensik_Linguis_sebagai Saksi_AHli.

[5] Sudyana, D. Etika dan profesionalisme saksi ahli. Yogyakarta: Universitas Islam Indonesia. 2015. https://www.academia.edu/16480565/Etika_dan_Profesionalisme_Saksi_Ahli.

[6] Hutchinson, C. T. ( 2012). "What is an Expert Witness? (Rule 702)" dalam Expert Witness Answer. Dostupné na Internet: http://www.pli.edu/product_files/EN00000000145819/89208.pdf: (Accessed on

May 2 , 2020). https://legacy.pli.edu/product_files/Titles/7625/Essential\%20Trial\%20Evid\%20sample\% 20for\%20product\%20page_20170628162540.pdf.

[7] Purwo BK. Pragmatik dan Pengajaran Bahasa: Menyibak Kurikulum 1984. Kanisius; 1990. 214 p. http://library.um.ac.id/free-contents/download/pub/download-print5.php/21099.pdf

[8] Wijana. Dasar-Dasar Pragmatik . $\quad$ Yogyakarta: Andi. 1996. https://www.worldcat.org/title/dasar-dasar-pragmatik/oclc/225654362.

[9] Levinson, S. C. Pragmatics. Cambridge: University Press. 1983. https://www.worldcat.org/title/pragmatics/oclc/1036807051.

[10] Leech, G. Prinsip-prinsip Pragmatik. Jakarta: Universitas Indonesia. 2015. http://lib.ui.ac.id/detail.jsp?id=1573.

[11] Asim, G. Kesantunan Negatif di Kalangan Dwibahasawanan Indonesia-Jawa di Jakarta Kajian Sosio-Pragmatik. Jakarta: Lembaga Bahasa Unika Atma Jaya. 199. https://lib.atmajaya.ac.id/default.aspx?tabID=61\&src=a\&id=68726.

[12] Nababan, P. Ilmu Pragmatik: Teori dan Penerapannya. Jakarta: P2LPTK, Departemen Pendidikan dan Kebudayaan. 1987. http://library.um.ac.id/free-contents/index.php/buku/detail/ilmupragmatik-teori-dan-penerapannya-p-w-j-nababan-23571.html.

[13] Oktavianus. Analisis Wacana Lintas Bahasa. Padang: Andalas University Pres. 2006. https://www.worldcat.org/title/analisis-wacana-lintas-bahasa/oclc/171143746.

[14] Cummings L, Setiawati E. Pragmatik: sebuah Perspektif Multidisipliner. Pustaka Pelajar; 2007. 492 p. https://opac.perpusnas.go.id/DetailOpac.aspx?id=519817.

[15] Rusminto, N. E. Analisis Wacana Bahasa Indonesia. Bandarlampung: Universitas Lampung. 2006. 23 https://scholar.google.com/scholar?cluster=8128279040553470251\&hl=en\&oi=scholarr. 